\title{
PENGARUH PROGRAM BIMBINGAN ORANG TUA TERHADAP KETERAMPILAN BERBICARA ANAK TUNARUNGU KELAS TINGGI PADA TINGKAT SEKOLAH DASAR LUAR BIASA
}

\author{
Eni Rachmawati \\ SDLB Sumber Dharma Malang \\ email: enirachmawati_plb@yahoo.com
}

\begin{abstract}
Impaired auditory function in children with hearing impairment led to stunted children's language development, so the ability to monitor the production of language and speaking of children is limited. It effect of children with hearing impairment have problems in communicating with people listening environments, where the speaking is a communication tool. Parental guidance program is a program designed to utilize natural way parents interact with their children. This program contains the ways children develop speaking skills, combined with the Family Counseling Behavioral approach that takes the principles of human learning to train parents in child management. Speaking skills developed in the parental guidance program include: pronunciation, structure, vocabulary, fluency / smoothness, the contents of the conversation and comprehension of the speaker towards the contents of his conversation. So as a result children with hearing impairment can communicate using verbal language in the environment people hear. The purpose of this study is to describe the implementation of parental guidance program and assess program impact on speaking skills of children with hearing impairment. The procedure of this study was carried out with found the problem, define the study population, parental guidance program design, validate the program, designing a matter of pre-test and post test, validate of pre-test and posttest speaking skills, conduct pre-test, provide training to parents on how to guide the speaking skills of children, give parents time to implement the mentoring program at home, doing post-test, and then perform data analysis. This study uses a quantitative approach to Pre-Experimental type of research with study design One group pre testpost test design. The population examined in this study were children with hearing impairment in the High Class SDLB Sumber Dharma Malang which has 7 children. With data collection techniques using oral tests. Data analysis techniques with the Sign test. The results obtained with calculation of the critical value of $5 \%$ for the two sides of (1.96), is a fact that the $\mathrm{Z}$ value obtained in a matter of $(\mathrm{ZH}=2.27)$ is greater than the critical value of $5 \%$ two-sided $\mathrm{Z}(1,96)$ so that the zero hypothesis (Ho) is rejected and the working hypothesis (Ha) accepted. Based on this study we can concluded there is influence of the use of the Parent Guidance Program of the speaking skills of children with hearing impairment in the High Class SDLB Sumber Dharma Malang.
\end{abstract}

Keywords: Parent Guidance Program, Speaking Skills, Children With Hearing Impairment.

\begin{abstract}
Abstrak: Gangguan fungsi pendengaran pada anak tunarungu menyebabkan perkembangan bahasa anak terhambat, akibatnya kemampuan untuk memonitor produksi bahasa dan bicara anak tuna rungu terbatas. Hal tersebut menyebabkan anak tuna rungu mengalami hambatan dalam berkomunikasi dengan lingkungan orang mendengar, dimana bicara merupakan alat komunikasi. Program bimbingan orang tua merupakan program yang dirancang dengan memanfaatan cara alami orang tua berinteraksi dengan anak-anak mereka. Program ini berisikan cara-cara mengembangkan keterampilan berbicara anak yang dikombinasikan dengan pendekatan Behavioural dalam Family Counseling yang mengambil prinsip-prinsip belajar manusia untuk melattih orang tua dalam pengelolaan anak. keterampilan berbicara yang dikembangkan dalam program bimbingan orang tua meliputi : pelafalan, struktur, kosakata, kefasihan/kelancaran, isi pembicaraan dan pemahaman si pembicara terhadap isi pembicaraannya. Sehingga sebagai hasilnya anak
\end{abstract}


tunarungu dapat berkomunikasi menggunakan bahasa verbal dalam lingkungan orang mendengar. Tujuan penelitian ini adalah mendiskripsikan pelaksanaan program bimbingan orang tua serta mengkaji pengaruh program tersebut terhadap keterampilan berbicara anak tunarungu. Penelitian ini menggunakan pendekatan kuantitatif dengan jenis penelitian Pre-Eksperimental dengan rancangan penelitian One group pre test-post test design. Populasi yang diteliti dalam penelitian ini adalah anak tunarungu kelas tinggi di SDLB Sumber Dharma Malang yang berjumlah 7 anak. teknik pengumpulan data menggunakan metode tes lisan. Teknik analisis data dengan Sign test. Hasil penelitian diperoleh perhitungan dengan nilai kritis 5\% untuk dua sisi $(1,96)$, merupakan suatu kenyataan bahwa nilai $\mathrm{Z}$ yang diperoleh dalam hitungan $(\mathrm{ZH}=2,27)$ adalah lebih besar dari pada nilai kritis $\mathrm{Z} 5 \%$ dua sisi $(1,96)$ sehingga hipotesis nol (Ho) di tolak dan hipotesis kerja (Ha) diterima. Berdasarkan hasil penelitian dapat disimpulkan ada pengaruh penggunaan Program Bimbingan Orang Tua terhadap keterampilan berbicara anak tunarungu kelas tinggi di SDLB Sumber Dharma Malang .

Kata kunci : Anak Tunarungu, Keterampilan Berbicara, Program Bimbingan Orang Tua

\section{PENDAHULUAN}

Berdasarkan data Michigan Depatment of Education (2000), hanya $30 \%$ dari waktu anak usia sekolah yang digunakan disekolah, sementara $70 \%$ dari waktu mereka dihabiskan diluar sekolah. Diluar sekolah anak mendapat banyak pengetahuan yang sebagian besar didapat dari orang tua. Dengan kata lain, orang tua memiliki peranan yang sangat penting dalam pendidikan anak-anak mereka. Ditingkat sekolah, orang tua dapat membantu anak-anak mereka dengan membimbing anak mereka sehingga akan membawa dampak positif dalam pestasi akademik.

Namun, tidak jarang orang tua beranggapan sudah menyerahkan bimbingan anak mereka kepada pihak sekolah, sehingga mereka merasa tidak perlu memberikan kontribusi dalam upaya membantu pendidikan anak mereka. Padahal, proses belajar mengajar tidak hanya berhenti disekolah, dirumah orang tua adalah pendidik utama anak. Proses belajar anak akan terhenti dirumah jika orang tua tidak memberikan tanggapan atas apa yang ditanyakan anak. Kondisi seperti ini akan menyebabkan anak merasa frustasi, tidak ada tempat untuk menanyakan kesulitan yang sedang dihadapinya, merasa tidak bisa bekomunikasi dengan orang tuanya. Begitu pula diungkapkan dalam situs Educatin in USA, bimbingan orang tua terhadap anak-anak mereka sangat menentukan keberhasilan anak di masa depannya.

Demikian halnya dengan anak tunarungu, begitu pentingnya peran orang tua dalam pendidikan anak - anak mereka utamanya terhadap keterampilan berbicara. Seperti diungkapkan Somad dan Hernawati (1996 : 88), orang tua adalah penanggung jawab pendidikan paling utama anak yang harus mengerti tentang keterbatasan anak serta menerima sebagaimana adanya.

Bagi anak tunarungu untuk mengembangkan keterampilan berbicara merupakan proses yang kompleks, sebab salah satu syarat penting yang diperlukan dalam keterampilan berbicara adalah kemampuan mendengar. Gelfand (1948 : 437) mengungkapkan bahwa berbicara merupakan permasalahan utama yang dialami oleh anak tuna rungu dalam habilitasi dan pendidikan. Hal serupa juga diungkapkan oleh Sunardi dan Sunaryo (2007:192), yang menyatakan bahwa diakibatkan kehilangan kemampuan mendengar pada anak 
tunarungu, akan membatasi persepsi bicara anak serta kekurang mampuan untuk memonitor produksi bahasa dan bicaranya.

Kenyataan bahwa anak tunarungu mengalami gangguan dalam pendengarannya, mengakibatkan perkembangan bahasa anak pada tahap laling terhenti. Pada tahap laling, anak mendengar telah mengalami kematangan auditori sehingga mampu menyadari bunyi atau suara yang dihasilkan sendiri maupun orang lain dari hasil pengulangan bunyi-bunyi yang telah didengarnya, namun pengalamn tersebut tidak terjadi pada anak tunarungu. Oleh karena itu anak tunarungu tidak akan memberikan imbal balik dengan membuat suarasuara sendiri, sehinggga anak tunarungu tidak dapat berbicara jika tidak dilatih dengan kata lain bisu. Meskipun demikian, tidak menutup kemungkinan keterampilan tersebut dapat dikembangkan.

Keterampilan berbicara yang dimaksud oleh peneliti meliputi pelafalan, struktur, kosakata, kefasihan/kelancaran, isi pembicaraan, pemahaman. Menurut Tarigan (1981:15) berbicara adalah kemampuan mengucapkan bunyi-bunyi artikulasi atau kata-kata untuk mengekspresikan, menyatakan serta menyampaikan pikiran, gagasan, dan perasaan. Tujuan utama dari berbicara adalah untuk berkomunikasi, untuk itu sang pembicara harus memahami makna segala sesuatu yang dikomunikasikannya dan menyampaikan gagasan pikiran secara efektif.

Peran orang tua sangat penting dalam proses belajar-mengajar, tidak hanya di rumah tapi juga di sekolah. Diperlukan komunikasi yang berkesinambungan antara orang tua dengan pihak sekolah untuk berdiskusi mencari solusi yang terbaik untuk penanganan anak. Dalam usaha mengembangkan keterampilan berbicara anak memerlukan latihan yang terus menerus, orang tua harus membimbing anak mereka tentu saja dengan cara yang menyenangkan dan tanpa adanya paksaan yakni dengan jalan mengkomunikasikan segala kegiatan bersama anak baik di rumah maupun di tempat-tempat umum. Luppin (2010 : 14) mendiskripsikan bimbingan sebagai suatu proses layanan yang diberikan kepada individuindividu guna membantu mereka memperoleh pengetahuan dan keterampilan yang diperlukan dalam membuat pilihan dan rencana yang diperlukan untuk menyesuaikan diri yang baik. Orang tua memberikan contoh atau model bagi anak, berbicara dengan pelan yang mudah diikuti oleh anak dan orang tua siap memberikan kritik atau membetulkan apabila dalam berbicara anak berbuat suatu kesalahan. Hal ini dikarenakan peran orang tua dalam menjadi partner komunikasi dapat membangkitkan motivasi anak tunarungu untuk berbicara, membantu anak mengkoreksi pelafalan artikulasi yang diucapkan dan mengajarkan struktur bahasa secara tidak langsung.Tujuan Penelitian ini Mendiskripsikan pelaksanaan dan menemukan pengaruh program bimbingan orang tua terhadap ketrampilan berbicara anak tunarungu kelas tinggi di SDLB Sumber Dharma.

\section{Manfaat Penelitian}

1. Manfaat Teoritis

Dari segi teoritis penelitian ini diharapkan membawa manfaat dalam menambah khasanah keilmuan kebahasaan terutama ketrampilan berbicara anak tunarungu.

2. Manfaat Praktis 


\begin{abstract}
Dari segi praktis penelitian ini diharapkan berguna bagi mahasiswa, orang tua, guru dan kepala sekolah untuk mengembangkan ketrampilan berbicara anak tunarunggu.
\end{abstract}

\section{KAJIAN PUSTAKA}

Istilah tunarungu diambil dari kata "Tuna" dan "Rungu". Tuna artinya kurang dan Rungu artinya pendengaran. Berbagai batasan telah dikemukakan oleh para ahli mengenai pengertian tunarungu (hearing impairment) yang meliputi Tuli (Deaf) dan Kurang Dengar (Hard of Hearing).

Menurut Somantri (2006: 93) "ketunarunguan dibedakan menjadi dua kategori yaitu tuli (deaf) dan kurang dengar (hard of hearing). Tuli adalah mereka yang indra pendengarannya mengalami kerusakan dalam taraf berat sehingga pendengaran tidak berfunngsi lagi. Sedangkan kurang dengar adalah mereka yang indra pendengarannya mengalami kerusakan tetapi masih dapat berfungsi untuk mendengar, baik dengan maupun tanpa menggunakan alat bantu dengar."

Ketunarunguan yang dialami oleh seorang anak akan menyebabkan konsekuensi yang kompleks bagi anak, terutama perkembangan anak menjadi sangat terhambat. Effendi (2006:55) menyataka bahwa diakibatkan gangguan pendengaran yang dialami, anak akan mengalami berbagai hambatan dalam meniti perkembangannya, terutama pada aspek bahasa, kecerdasan dan penyesuaian sosial.

Dalam Sadjaah dan Sukarja (1995:116) Hallahan dan Kaufman mengemukakan, ketidakmampuan berbahsa/bicara disebabkan oleh tiga faktor yang saling berkaitan yaitu:

1. Penerimaan bunyi memalui pendengaran tidak cukup sebagai umpan balik untuk menyuarakan bunyi. Sebagai akibat gangguan pendengaran, maka bunyi yang didengarnya tidak sempurna.

2. Penerimaan bahasa/bicara dari orang yang sengaja mengajak bicara, tidak cukup untuk menunjang pendengarannya.

3. Anak tunarungu tidak mampu mendengar contoh bahasa/bicara dari orang yang mengajak bicara. Oleh karena perbendaharaan kata kurang, anak tunarungu sulit menginterpretasikan gerak bicara orang lain.

Dalam kehidupannya anak tunarungu akan masuk ke dalam lingkungan orang mendengar. Namun keadaan yang dialami anak tunarungu menyebabkan anak memerlukan perhatian khusus. Untuk mencapai tujuan tersebut peran orang tua dalam upaya meningkatkan keterampilan berbicara anak tunarungu sangat dibutuhkan.

Alasan mengapa orang tua dikatakan sangat berperan dalam perkembangan berbicara anak adalah imitasi. Hakikatnya manusia belajar dengan melihat, mendengar dan kemudian mengimitasi. Dengan melihat manusia tahu, dengan mendengar manusia mengerti, dengan mengimitasi dan terlibat maka manusia akan memahami. Orang yang pertama dan selalu berada disekitar anak adalah orang tua.

Orang pertama yang dipercaya oleh anak adalah orang tua. Orang pertama yang ingin diimitasi oleh anak adalah orang tua. Orang pertama yang ingin dibuat bangga oleh anak adalah orang tua. Oleh sebab itu orang tua yang hebat akan mendorong anak untuk bisa menjadi seperti mereka bahkan melampaui mereka. Seperti halnya keterampilan berbicara anak tunarungu yang dikuasai dengan cara imitasi, peniruan terjadi apabila ada motivasi 
dari anak, dan motivasi muncul apabila ada interaksi antara anak dan orang tua. Itulah kenapa orang tua harus dapat membimbing anak mereka dengan sering mengadakan komunikasi guna merangsang motivasi anak untuk berbicara sebagai imbal balik umpan yang diberikan oleh orang tua. Hal tersebut dapat memberikan pengaruh terhadap keterampilan berbicara anak, secara konsisten orang tua melakukan percakapan dirumah bersama dengan anak, sehingga keterampilan berbicara anak akan terasah.

Sunardi dan Sunaryo (2007:193) menyatakan, MacDonald dan Gillete mencatat bahwa keterlambatan perkembangan bahasa dan bicara anak tunarungu cenderung disebabkan ketidakmampuan orangtua dan orangorang lain yang signifikan dengan anak tunarungu untuk berfungsi sebagai partner komunikasi yang baik. Itulah pengaruh orang tua terhadap anak, serta alasan mengapa orang tua sangat perlu untuk membimbing anak mereka menghadapi keterbatasan yang dimiliki, membimbing anak menemukan jalan yang sesuai untuk mencapai apa yang seharusnya bisa dicapai oleh anak. Oleh sebab itu perlu adanya bimbingan dari orang tua untuk membantu dan mengarahkan anak mereka dalam tujuan membantu penguasaan keterampilan berbicara anak. Bantuan tersebut diwujudkan dalam bentuk pemberian program bimbingan orang tua dengan materi komponen-komponen dalam keterampilan berbicara meliputi fonologi, kosakata, struktur dan kecepatan kelancaran umum.

\section{METODE}

Pada penelitian ini, penulis menggunakan jenis penelitian PreEksperimental yang bersifat kuantitatif dengan rancangan penelitian "One Group Pre test - Post test Design."
Penelitian Pre- Eksperimental adalah sebuah eksperimen yang dilakukan pada suatu kelompok tanpa adanya kelompok kontrol atau pembanding.

Prosedur didalam penelitian ini observasi dilakukan sebanyak 2 kali yaitu sebelum eksperimen dan sesudah eksperimen. Observasi yang dilakukan sebelum eksperimen $\left(0_{1}\right)$ disebut pretest, dan observasi sesudah eksperimen $\left(\mathrm{O}_{2}\right)$ disebut post-test. Perbedaan antara $0_{1}$ dan $0_{2}$ yakni $0_{2}-0_{1}$ diasumsikan merupakan efek dari treatment atau eksperimen (Arikunto, $2006: 85$ )

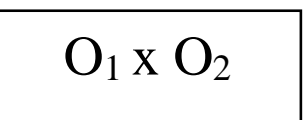

Keterangan :

$\mathrm{O}_{1}$ : tes awal atau pre test ( dilakukan untuk memperoleh data tentang keterampilan berbicara anak tunarungu kelas kabupaten Sidoarjo)

$\mathrm{X}$ : perlakuan atau treatment (pelaksanaan program bimbingan orang tua)

$\mathrm{O}_{2}$ : tes akhir atau post test (dilakukan untuk memperoleh data tentang peningkatan keterampilan berbicara anak tunarungu di SDLB Sumber Dharma setelah diintervensi)

Teknik analisis data yang digunakan untuk menganalisis data dalam penelitian desain one group pre-test and post test design (desain 2) adalah non parametrik dengan data kuantitatif. Maka rumus yang dipergunakan untuk menganalisis data dalam penelitian ini adalah rumus statistik non parametrik jenis Uji Tanda (Sign Test).

$$
z h=\frac{x-\mu}{\sigma}
$$

Keterangan:

$$
\begin{array}{ll}
\mathrm{Zh} & : \text { nilai hasil } \\
\mathrm{X} & : \text { deviasi }
\end{array}
$$




$$
\begin{array}{lll}
\mu & \text { (miu) } & : \text { rata-rata } \\
\sigma & (\text { tau }) & : \text { harga } \sqrt{n p q}
\end{array}
$$

(Saleh, $1996: 5)$

\section{HASIL DAN PEMBAHASAN}

Analisis data dilakukan dengan cermat dan teliti agar tidak menimbulkan kekeliruan dalam menarik kesimpulan. Dalam menganalisis data, peneliti menggunakan rumus statistik non parametrik dengan rumus uji tanda. Adapun langkah-langkah analisis data sebagai berikut :

a. Membuat tabel kerja uji tanda

Tabel 1 menyajikan data tentang hasil tes sebelum dan sesudah dilakukan intervensi dengan memberikan program bimbingan orang tua, berikut ini adalah prosedur penentuan jumlah tanda positif dan negatifnya.

\section{Tabel 1. Rekapitulasi Tabel Kerja Nilai Pre Test dan Post Test}

b. Menghitung rumus uji tanda Data-data hasil penelitian yang berupa nilai pre test dan pos test yang telah dimasukkan dalam rekapitulasi tabel kerja perubahan diatas, kemudian dianalisis menggunakan rumus sign tes $\left(Z_{h}\right)$. Perhitungan statistik dengan menggunakan rumus uji tanda (sign tes) ;

1) $\mathrm{Z}_{\mathrm{h}} \frac{\chi-\mu}{\sigma}$ il pengamatan dan hasil perhitungan diperoleh perubahan tanda $(+)=7$, maka besar $\chi$ adalah :

$\chi=$ tanda plus $-0,5$

$\chi=7-0,5=6,5$ jadi besarnya $\chi$ terletak pada $\chi=6,5$
2) Mencari $p$

Probabilitas untuk memperoleh tanda (+) atau $(-)=0,5$ karena nilai kritis $\mathrm{Za}=5 \%$

3) Mencari $q$

$$
\begin{aligned}
\mathrm{q} & =1-\mathrm{p} \\
& =1-0,5 \\
& =0,5
\end{aligned}
$$

4) Mencari $\mu$ (mean)

$$
\begin{aligned}
\mu & =\mathrm{n} \cdot \mathrm{p} \\
& =7 \cdot 0,5 \\
& =3,5
\end{aligned}
$$

\begin{tabular}{|c|c|c|c|c|c|}
\hline \multirow[b]{2}{*}{ No. } & \multirow[b]{2}{*}{ Nama } & \multirow[b]{2}{*}{$\begin{array}{c}\mathbf{L} \\
/ \mathbf{P}\end{array}$} & \multicolumn{2}{|c|}{ Nilai } & \multirow{2}{*}{$\begin{array}{l}\text { Perubahan } \\
\text { tanda } \\
\qquad \mathbf{T}_{1}-\mathbf{T}_{2}\end{array}$} \\
\hline & & & $\begin{array}{l}\text { Pre } \\
\text { Test }\end{array}$ & $\begin{array}{l}\text { Post } \\
\text { Test }\end{array}$ & \\
\hline 1 & $\mathrm{Aa}$ & $\mathrm{L}$ & 47 & 68 & + \\
\hline 2 & $\mathrm{Nn}$ & $\mathrm{L}$ & 41 & 65 & + \\
\hline 3 & $\mathrm{Rk}$ & $\mathrm{L}$ & 38 & 57 & + \\
\hline 4 & $\mathrm{Ld}$ & $\mathrm{P}$ & 32 & 56 & + \\
\hline 5 & Ls & $\mathrm{P}$ & 31 & 56 & + \\
\hline 6 & Wy & $\mathrm{L}$ & 24 & 30 & + \\
\hline 7 & M & $\mathrm{L}$ & 27 & 34 & + \\
\hline \multicolumn{3}{|c|}{ Rata-rata } & 33 & 52 & + \\
\hline
\end{tabular}

5) Mencari $\sigma$

$$
\begin{aligned}
\sigma & =\sqrt{ } \text { n.p.q } \\
& =\sqrt{ } 7 \mathrm{x} 0,5 \times 0,5 \\
& =\sqrt{ } 1,75 \\
& =1,3228575 \\
& =1,32
\end{aligned}
$$

6) Memasukkan ke dalam rumus

$$
\begin{aligned}
Z_{\mathrm{h}} & \frac{\chi-\mu}{\sigma} \\
= & \frac{6,5-3,5}{1,32}
\end{aligned}
$$

$$
\begin{aligned}
& =2,272727 \\
& =2,27
\end{aligned}
$$

c. Pengujian hipotesis

1) Tes Statistik

2) $\mathrm{Z}_{\mathrm{h}}=\frac{\chi-\mu}{\sigma}$

Nilaj uk $\alpha=5 \%$

(pengujian dilakukan dengan 
dua sisi), maka nilai kritis $=$ $\pm Z^{1} 1 / 2 \alpha= \pm 1,96$

Ho diterima bila $-1,96 \leq+$ 1,96

Ho ditolak bila $\mathrm{Zh}>+1,96$ atau $\mathrm{Zh}<-1,96$

Berdasarkan pengolahan data yang diperoleh maka $\mathrm{Zh}=2,27$ dengan nilai kritis $=0,05$ maka Ho ditolak dan hipotesis kerja diterima. Hal ini berarti ada pengaruh bimbingan orang tua yang signifikan terhadap keterampilan berbicara anak tunarungu kelas tinggi di SDLB Sumber Dharma Malang. Berdasarkan data yang diperoleh dari analisis yang menggunakan rumus uji tanda tersebut dapat dilihat bahwa ada peningkatan keterampilan berbicara dengan adanya tanda positif (+) pada program bimbingan orang tua tersebut $\mathrm{Zh}=2,27$ sehingga dapat diketahui bahwa di kelas tinggi SDLB Sumber Dharma penerapan program bimbingan orang tua dapat memberikan pengaruh yang signifikan terhadap keterampilan berbicara anak tunarungu kelas tinggi SDLB Sumber Dharma dengan ditunjukkan adanya perubahan hasil dari penerapan program bimbingan orang tua terhadap keterampilan berbicara anak tunarungu, baik sebelum dan sesudah diberikan intervensi menunjukkan perbedaan.

\section{SIMPULAN}

Sebelum dilakukan intervensi menggunakan program bimbingan orang tua diperoleh data dari 7 anak tunarungu kelas tinggi SDLB Sumber Dharma, 4 diantaranya memiliki nilai keterampilan berbicara berada di bawah rata-rata nilai keseluruhan jumlah populasi yaitu dibawah rata-rata nilai 33. Setelah dilakukan intervensi menggunakan penerapan program bimbingan orang tua, keterampilan berbicara anak tunarungu kelas tinggi
SDLB Sumber Dharma mengalami perubahan, meskipun tidak menunjukkan peningkatan angka yang besar. Diantara 6 anak dari populasi memiliki nilai diatas rata-rata 55. Hal tersebut disesabkan tingkat kesulitan soal yang dirancang oleh peneliti, untuk romawi I tingkat soal mudah tingkat berisi tentang pelafalan bicara peningkatan keterampilan anak meningkat secara signifikan, untuk romawi III dengan tingkat soal sulit dengan soal berisi pemahaman pembicara atas apa yang disampaikan keterampilan anak juga meningkat secara signifikan, tapi untuk romawi II dengan tingkat soal sangat sulit yang pada tingkat akhir adalah menyusun kalimat, peningkatan tidak terjadi secara signifikan, karena kalimat merupakan susunan kata yang kompleks dan memerlukan pemahaman atas struktur kalimat dan kosa-kata yang luas.

Penerapan program bimbingan orang tua terhadap keterampilan berbicara anak tunarungu kelas tinggi SDLB Sumber Dharma, memperoleh hasil pengolahan data dengan menggunakan rumus uji tanda, dan diperoleh $\mathrm{Zh}=2,27$ sedangkan $\mathrm{Z}$ 0,05 $=1,96$. Angka tersebut membuktikan bahwa penerapan program bimbingan orang tua dapat mempengaruhi keterampilan berbicara anak tunarungu kelas tinggi SDLB Sumber Dharma. Hal tersebut sama seperti yang diungkapkan oleh Henderson \& Mapp (2002) yang menemukan bahwa tingkat keterlibatan orang tua mempengaruhi prestasi anak mereka secara langsung.

\section{DAFTAR PUSTAKA}

Abdurachman, Dudung dan Sugiarto, Moch. 1999. Pedoman Guru Pengajaran Wicara untuk Anak Tunarungu. Jakarta : Depdiknas. 
Amin, Samsul Munir. 2010. Bimbingan dan Konseling Islam. Jakarta : AMZAH.

Arikunto, Suharsimi. 2003. DasarDasar Evaluasi Pendidikan. Jakarta : Bumi Aksara.

Bunawan, Lani dan Yuwati, Cecilia Susila. 2000. Penguasaan Bahasa Anak Tunarungu. Jakarta : Yayasan Shanti Rama.

Darta, Hanny Muchtar. 2011. Sixs Pllars of Positive Parenting. Jakarta : Cicero Publishing.

Effendi, Mohammad. 2006. Pengantar Psikopedagogik Anak Berkelainan. Jakarta : Bumi Aksara.

Gelfand, Stanley A. 1948. Essentials of Audiology. New York : Thieme Medical Publisher. Inc.

Ghazali, Syukur. 2010. Pembelajaran Keterampilan Berbahasa dengan Pendekatan Komunikatif-Interaktif. Bandung : Refika Aditama.

Graha, Chairinniza. 2008. Keberhasilan Anak Ditangan Orang Tua. Jakarta : Gramedia.

Gregory, Susan dkk. 1998. Issue In Deaf Education. London : David Fulton Publisher Ltd.

HN, Suhaeri dan Purwanta, Edi. 1996. Bimbingan Konseling Anak Luar Biasa. Jakarta : Depdikbud.

Luddin, Abu Bakar M. 2010. DasarDasar Konseling. Bandung : Citapustaka Media Perintis.
Monks, F J dkk. 2004. Psikologi Perkembangan : Pengantar Dalam Berbagai Bagian. Yogyakarta : GADJAH MADA UNIVERSITY PRESS.

Sadjah, Edja dan Sukarja, Dardjo. Tanpa Tahun. Bina Bicara, Persepsi Bunyi dan Irama. Bandung : Depdikbud.

Saleh, Samsubar. 1996. Statistik Nonparametrik. Yogyakarta : BPFE-Yogyakarta.

Semiaan, Conny R. 2009. Penerapan Pembelajaran pada Anak. Jakarta : PT. INDEKS.

Somad, Permanarian dan Hernawati, Tati. 1996. Ortopedagogik Anak Tunarungu. Bandung : Depdikbud.

Somantri, Sutjihati. 2006. Psikologi Anak Luar Biasa. Bandung : Refika Aditama.

Sunardi dan Sunaryo. 2007. Intervensi Dini Anak Berkebutuhan Khusus. Jakarta : Depdiknas.

Tarigan, Henry Guntur. Tanpa Tahun. Berbicara Sebagai Suatu Keterampilan Berbahasa. Bandung : Angkasa.

Tarigan, Henry Guntur. 1985. Pengajaran Kosa Kata. Bandung : Angkasa.

Tarmansyah. 1996. Gangguan Komunikasi. Jakarta : Depdikbud. 